\title{
Can the introduction of Xenopus laevis affect native amphibian populations? Reduction of reproductive occurrence in presence of the invasive species
}

\author{
Francesco Lillo • Francesco Paolo Faraone • \\ Mario Lo Valvo
}

Received: 7 January 2010/Accepted: 15 November 2010/Published online: 26 November 2010

(C) Springer Science+Business Media B.V. 2010

\begin{abstract}
Biological invasions are regarded as a form of global change and potential cause of biodiversity loss. Xenopus laevis is an anuran amphibian native to sub-Saharan Africa with strong invasive capacity, especially in geographic regions with a Mediterranean climate. In spite of the worldwide diffusion of $X$. laevis, the effective impact on local ecosystems and native amphibian populations is poorly quantified. A large population of X. laevis occurs in Sicily and our main aim of this work was to assess the consequences of introduction of this alien species on local amphibian populations. In this study we compare the occurrence of reproduction of native amphibians in ponds with and without $X$. laevis, and before and after the alien colonization. The results of our study shows that, when $X$. laevis establishes a conspicuous population in a pond system, the populations of Discoglossus pictus, Hyla intermedia and Pelophylax synklepton esculentus show clear signs of distress and the occurrence of reproduction of these native amphibians collapses. In contrast, the
\end{abstract}

F. Lillo · F. P. Faraone - M. Lo Valvo ( $₫)$

Dipartimento di Biologia Animale "G. Reverberi", Università di Palermo, Via Archirafi 18, 90123 Palermo, Italy

e-mail: mlovalvo@unipa.it

F. Lillo

e-mail: francesco.lillo@gmail.com

F. P. Faraone

e-mail: paolofaraone@unipa.it populations of Bufo bufo do not appear to be affected by the alien species. Since the Sicilian population of $X$. laevis shows a strong dispersal capacity, proportionate and quick interventions become necessary to bound the detriment to the Sicilian amphibians populations.

Keywords Xenopus laevis - Alien invasive species · Sicily $\cdot$ Amphibians conservation .

Biological invasion

\section{Introduction}

Biological invasions are regarded as a form of global change (Ricciardi 2007). Many human activities, such as agriculture, aquaculture, recreation and transportation, are the cause of intentional or accidental spread of species away from their natural ranges of distribution (Gherardi et al. 2008). Although most new species fail to establish viable populations, those that persist can threaten native biodiversity and ecosystem functionality, and may have detrimental effects on human health as well as economic impacts (Kolar and Lodge 2001). Compared to terrestrial ecosystems, aquatic ecosystems have proven particularly vulnerable to invasive alien species (Sala et al. 2000).

The direct link between invasiveness and impact on the host ecosystems of an alien species is not 
easily demonstrable (Ricciardi and Cohen 2007). Alien invasive species are among the main causes of global amphibian decline (Beebee and Griffiths 2005; Kats and Ferrer 2003). The introduction of predatory fish, crustaceans and non-native amphibians can strongly threaten the native amphibian populations via competition, predation, diffusion of diseases or other interactions (e.g., Garner et al. 2006; Hecnar and M'Closkey 1997; Kats and Ferrer 2003).

After the American bullfrog (Lithobates catesbeianus) and cane toad (Bufo (Chaunus) marinus), the African clawed frog Xenopus laevis is probably the invasive amphibian species with the greatest worldwide diffusion. It is native to sub-Saharan Africa and is a totally aquatic species that lives in most types of water bodies with preference for stagnant or still waters in ponds or sluggish streams (Tinsley et al. 1996). The African clawed frog has specific adaptations to aquatic life, including retention of the lateral line system in adults, aquatic chemoreceptors (Elepfandt 1996a, b; Elepfandt et al. 2000) and a body structure particularly adapted for swimming (Videler and Jorna 1985). However, it also has a remarkable ability to migrate overland (Eggert and Foquet 2006; Faraone et al. 2008a; Measey and Tisley 1998).

The worldwide spread of the African clawed frog is due to trade started in the 1930s. After the development of a pregnancy assay using African clawed frogs as a test animal, as well as its use as a model in development biology (Gurdon 1996; Keller and Lodge 2007; Weldon et al. 2007). The aforementioned biological characteristics and strong adaptability of the African clawed frog has resulted in its success as an invasive species, particularly in geographic regions with a Mediterranean climate (Lobos and Measey 2002; Tinsley and McCoid 1996). Non-native and invasive populations of African clawed frog are present in the US states of Arizona and California (Crayon 2005), Ascension Island (Tinsley and McCoid 1996), Chile (Lobos and Measey 2002), France (Fouquet 2001), Wales (Measey and Tisley 1998), Sicily (Lillo et al. 2005) and Portugal (Rebelo et al. 2010). Although many studies investigate the biology and the ecology of African clawed frogs in their invasive environments (e.g., Fouquet and Measey 2006; Lobos and Jaksic 2005; Measey and Tisley 1998), to our knowledge no studies examine the effects of this alien species on populations of native amphibians.
The African clawed frog is a proficient generalist predator, implicated in ingestion of endangered and rare species [e.g., Gasterosteus aculeatus williamsoni (Tinsley and McCoid 1996); Eucyclogobius newberryi (Lafferty and Page 1997)], as well as amphibians. For example, stomach contents of African clawed frogs have been found to have low numbers of Bufo boreas (one of 39 stomachs; Crayon 2005). Similarly, in a previous study on Sicilian populations of African clawed frog, we recorded the presence of a Bufo bufo tadpole among 306 stomachs examined (Faraone et al. 2008b). The African clawed frog is also considered as the probable origin of the spread, and a vector of, the chytridiomycosis fungus Batrachochytrium dendrobatidis (Weldon et al. 2004). Despite the aforementioned observations that lead to a legitimate concern for native species, few studies provide details of the impact of African clawed frogs on host ecosystems, particularly local populations of amphibians. Since the discovery of African clawed frogs in Italy in 2004 (Lillo et al. 2005), the need for an in-depth investigation on the possible consequences of its introduction on ecosystems is vital.

The aim of this study is to clarify if the establishment of an invasive population of African clawed frogs influences native amphibian populations. Specifically, we aimed to evaluate:

1. The difference in the reproductive occurrence and population structure of native amphibians in ponds with and without African clawed frogs

2. The change in reproductive occurrence of amphibian assemblages during the colonization process of the African clawed frog

3. The trophic overlap between an aquatic native amphibian and the African clawed frog.

\section{Materials and methods}

Study area and amphibian species

We conducted our study in the catchment basins of the rivers Belice Destro and Jato, Sicily, Italy. This area is $15 \mathrm{~km}$ wide $\left(37^{\circ} 52^{\prime}-38^{\circ} 0^{\prime} \mathrm{N}\right)$ and $27 \mathrm{~km}$ long $\left(12^{\circ} 56^{\prime}-13^{\circ} 14^{\prime} \mathrm{E}\right)$ and is mainly agricultural land, cultivated with vineyards, olive groves and cornfields. It also includes a large reservoir (Lake Poma) and hundreds of agricultural ponds with surface areas 
ranging between 100 and $2,000 \mathrm{~m}^{2}$. Faraone et al. (2008a) showed that this region has a large invasive population of African clawed frog, with a distribution surface of $\sim 225 \mathrm{~km}^{2}$ in 2005 .

The catchment basins include five native amphibians: the common toad Bufo bufo, the endemic Sicilian green toad B. siculus, the painted frog Discoglossus pictus, the Italian tree frog Hyla intermedia and the Italian complex of green frog Pelophylax synklepton esculentus. The agricultural ponds are important sites for reproduction of all these amphibians except for the Sicilian green toad that is rare in agricultural ponds and prefers temporary ponds for reproduction (Sicilia et al. 2006), so our study focuses on the other four native amphibians.

Sampling and analysis

On 34 occasions between 2005 and 2008, we conducted sampling trips at 68 ponds within the study area. Each pond was sampled at least one time for season. During each sampling period we recorded (1) the presence/absence of African clawed frogs in the ponds, (2) the occurrence of reproduction of the native amphibians in the same ponds, and (3) the colonization of new ponds by African clawed frog from year to year. The presence of amphibians was evaluated through visual observation and with the aid of dipnets. The detection of the presence of African clawed frog is facilitated by its respiratory behaviour: African clawed frogs spend in fact, most of their time underwater, periodically performing rapid surfacing in order to breathe (Ihmied and Taylor 1995). The surfacing individuals are easily identifiable by observing the surface of the ponds. Each pond was sampled for at least $30 \mathrm{~min}$ by two experienced observers. In the case of doubtful observations, the sampling was repeated a few days later, otherwise the pond was discarded for the analysis.

During 2007, to evaluate the consequences of the presence of African clawed frogs in the ponds, we selected, between the 68 ponds sampled, 45 ponds that appeared optimal for reproduction of native amphibians. These ponds was divided in two groups: one group of ponds included those impacted by the presence of African clawed frogs (IMP; $n=26$ ) and one group of control ponds without the alien species (CTR; $\mathrm{n}=19)$. We compared the IMP and CTR ponds ( $t$ test) about their environmental variables (Table 1).

We used a $\chi^{2}$ test to compare the different occurrence of reproduction of native amphibians between IMP and CTR ponds. The number of ponds sampled for each species was the following: 26 IMP ponds and 18 CTR ponds for green frogs; 18 IMP ponds and 10 CTR ponds for common toads; 18 IMP ponds and 11 CTR ponds for painted frogs; 17 IMP ponds and 14 CTR ponds for Italian tree frogs. In the case of no significant differences between IMP and CTR ponds we evaluated the difference of relative abundance of tadpoles collected by dipnets as described by Scott and Woodward (1994). The method consists of dragging the net $(25 \times 20 \mathrm{~cm})$ for a note tract $(1.5 \mathrm{~m})$ proportionally to the length of the pond edge (every $10 \mathrm{~m}$ ). A one-way ANOVA was applied to examine the difference of the relative abundance of tadpoles between the pond groups.

To evaluate the yearly variation of the reproductive occurrence of native amphibians we focused observing a focal pond for four consecutive years (2005-2008). The focal pond was Xenopus-free in 2005 and colonized for the first time in 2006. To verify the presence of African clawed frogs we conducted yearly repeated samplings between May

Table 1 Comparison between the environmental characteristics of pond with Xenopus laevis (IMP) and ponds without the alien species (CTR)

\begin{tabular}{|c|c|c|c|c|c|c|c|}
\hline \multirow[t]{2}{*}{ Pond characteristics } & \multirow{2}{*}{$\begin{array}{l}\text { IMP }(n=26) \\
\text { Mean } \pm \text { SE }\end{array}$} & \multirow{2}{*}{$\begin{array}{l}\text { CTR }(n=19) \\
\text { Mean } \pm \text { SE }\end{array}$} & \multicolumn{3}{|l|}{$t$ test } & \multicolumn{2}{|c|}{ All ponds $(n=45)$} \\
\hline & & & $t$ & $d f$ & $P$ & Mean $\pm \mathrm{SE}$ & Range \\
\hline Surface area $\left(\mathrm{m}^{2}\right)$ & $824.0 \pm 36.5$ & $831.6 \pm 27.9$ & 0.15 & 43 & 0.88 & $827.2 \pm 23.9$ & $600-1500$ \\
\hline Maximum depth (m) & $3.7 \pm 0.2$ & $3.5 \pm 0.2$ & 0.53 & 43 & 0.60 & $3.6 \pm 0.1$ & $2-5$ \\
\hline Riparian vegetation (\%) & $34.4 \pm 2.0$ & $35.8 \pm 2.3$ & 0.44 & 43 & 0.66 & $35.0 \pm 1.5$ & $25-50$ \\
\hline Altitude (m asl) & $316.7 \pm 9.7$ & $327.7 \pm 13.3$ & 0.68 & 43 & 0.50 & $321.4 \pm 7.9$ & $200-450$ \\
\hline Surrounding area (\% vineyards) & $68.3 \pm 4.7$ & $72.4 \pm 5.4$ & 0.57 & 43 & 0.57 & $70.0 \pm 3.5$ & $25-100$ \\
\hline
\end{tabular}


and August using a plastic dredge (see Faraone et al. 2008a; $100 \mathrm{~cm} \times 100 \mathrm{~cm} \times 50 \mathrm{~cm}, \mathrm{~L} \times \mathrm{W} \times \mathrm{H}$ ). The occurrence of reproduction of all amphibians in the pond was evaluated by presence/absence of spawning, larvae and postmetamorphs. Furthermore we recorded the relative abundance of tadpoles for each amphibian species, as the number of tadpoles observed during a complete turn of the pond edge. We used a scale of abundance as follows: abundant ( $>50$ in at least one sampling during the year), low (10-50), present (1-9), absent (0).

To evaluate the possible trophic competition between the native amphibians and the African clawed frog we compared their with that of the green frog. The green frog has the strongest aquatic ecology, living in close contact with the water throughout the year (Lanza et al. 2007). The painted frog, Italian tree frog and common toad only use the aquatic ecosystems during their reproductive period. During five sampling periods between July and September 2006, we collected stomach contents of African clawed frog and green frog in two neighbor and similar ponds. To avoid interferences we selected a Xenopus-free pond to collect green frogs. The African clawed frogs were collected by using a plastic dredge and green frogs using dipnets. The stomach contents were collected through the stomach flushing method (Solé et al. 2005), and prey items identified using a stereo-microscope. We distinguished prey types at the level of Order. Furthermore, we distinguished the prey types as adults, larvae, nymphs or pupae and for their aquatic and nonaquatic ecology. The Orders that occurred in stomach contents of both amphibians were identified to the level of Family. The percentage of every prey type was calculated. To estimate the overlap of the diets of two amphibian species we used the Pianka Index. The values of this index vary from 0 (no overlap) to 1.0 (complete overlap) with 0.75 indicating high overlap and values less than 0.4 indicating low overlap (Pianka 1973).

\section{Results}

During the firs year, 35 ponds of $68(51.5 \%)$ was colonized by African clawed frog. In 2008 we found the species in 47 ponds $(69.1 \%)$. The timing of occurrence of spawns, larvae and metamorphs of all

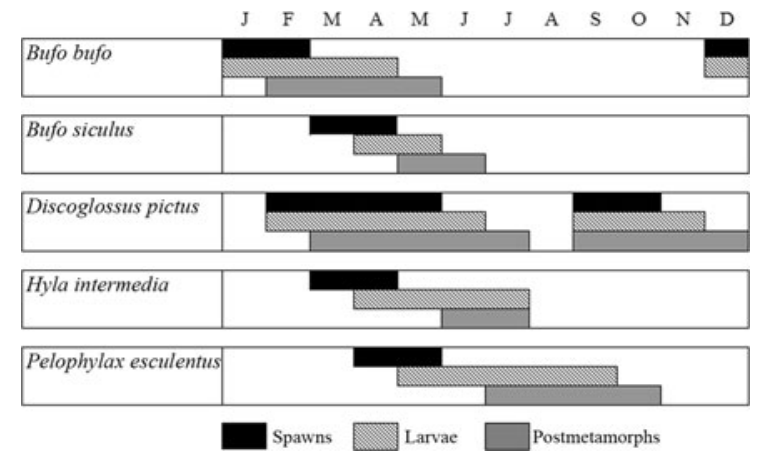

Fig. 1 Timing of occurrence of spawns, larvae and postmetamorphs of all native species in the study area

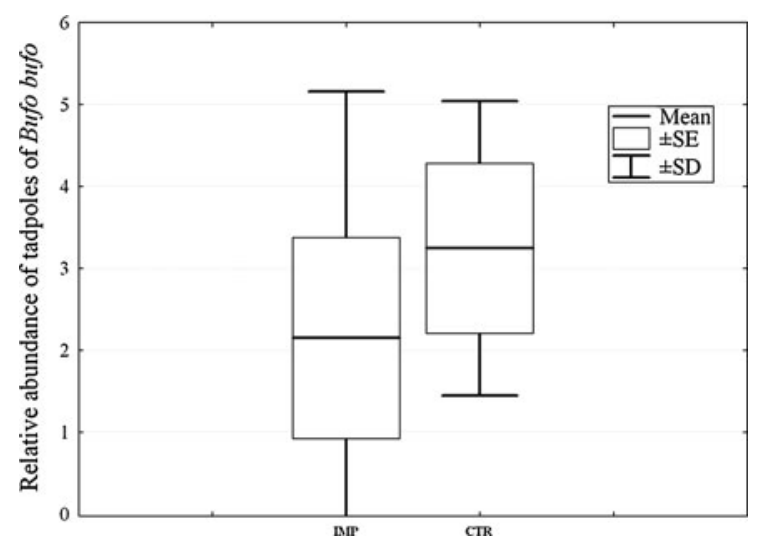

Fig. 2 Mean, SE and SD of relative abundance of B. bufo tadpoles in IMP and CTR ponds

five native species in the study area is shows in Fig. 1.

The comparison between IMP and CTR ponds showed no statistically significant differences for all their environmental variables. Occurrence of reproduction was higher in CTR ponds than IMP ponds for green frogs $\left(\chi^{2}=14.65 ; P<0.001\right)$, painted frogs $\left(\chi^{2}=23.52 ; \quad P<0.001\right)$ and Italian tree frogs $\left(\chi^{2}=6.1 ; P=0.013\right)$. However, the occurrence of reproduction of common toads did not differ in ponds with and without African clawed frogs $\left(\chi^{2}=0.003\right.$; $P=0.96$ ) (Fig. 2). Similarly, the relative abundance of tadpoles of common toads, evaluated by one-way ANOVA, did not differ between ponds with and without African clawed frogs (Average IMP $=2.15$ $(\mathrm{SE}= \pm 1.23)$, Average $_{\mathrm{CTR}}=3.24 \quad(\mathrm{SE}= \pm 1.04)$; $\mathrm{F}_{6,93}=1.39, P=0.22$ ) (Fig. 3). 


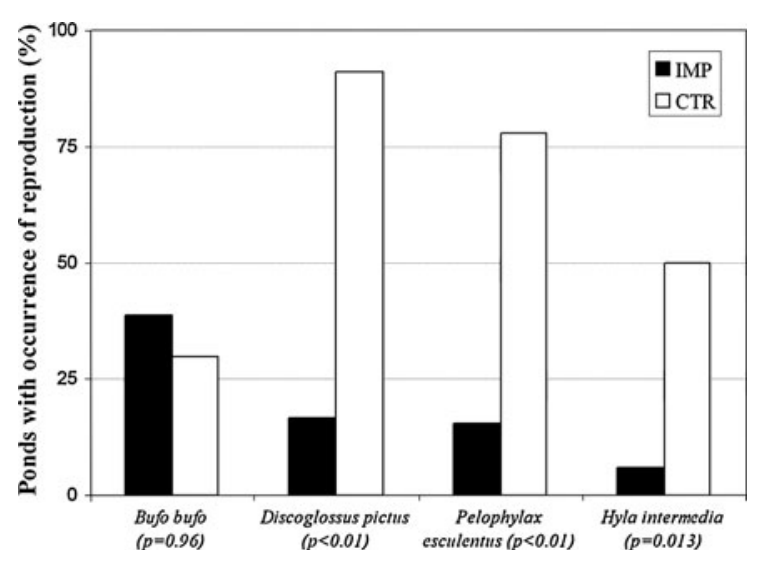

Fig. 3 Percentage of ponds with Xenopus laevis (IMP) and without $X$. laevis (CTR) that showed occurrence of reproduction of native amphibians during 2007

Table 2 Relative abundance of native and alien tadpoles in the focal pond during the colonization process by Xenopus laevis (2005 and 2008)

\begin{tabular}{lllll}
\hline & I Year & II Year & III Year & IV Year \\
\hline Bufo bufo & A & A & A & A \\
Discoglossus pictus & A & A & A & NP \\
Hyla intermedia & LP & LP & LP & NP \\
Pelophylax esculentus & A & A & A & NP \\
Xenopus laevis & NP & NP* & A & A \\
\hline
\end{tabular}

$A$ abundant, $L P$ low presence, $N P$ not present, $N P^{*}$ tadpoles absent but adults present. See "materials and methods" for details

Table 2 summarizes the yearly variation of reproductive occurrence in the focal pond for all amphibian species. During the observations conducted in 2005, we did not find African clawed frogs in the focal pond nor in the neighbouring ponds. In the same year the larvae of native amphibians were abundant (green frog, painted frog, common toad) or low (Italian tree frog) in the pond. In 2006 we observed few surfacing activities of African clawed frogs in the focal pond, but the repeated use of the dredge did not produce any capture because of their low density. Similarly, no tadpoles or postmetamorphs of African clawed frogs were observed and the relative abundance of native amphibian tadpoles was the same of the previous year. In 2007 the dredge captured eight adult and 164 tadpoles or postmetamorphs of African clawed frogs (ratio 0.05:1 adult: (tadpoles + postmetamorphs)). The occurrence of reproduction of native amphibians was again the same of the previous years. Finally, in 2008 the dredge captured 313 adult and 14 tadpoles or postmetamorphs of African clawed frog (ratio 22.4:1 adult: (tadpoles + postmetamorphs)), but no occurrence of reproduction was recorded for native amphibians in this year, except for the common toad. During these years the same pattern of colonization was observed in another eight ponds close to the focal pond and colonized by the alien species. On the contrary, four ponds where African clawed frog has not colonized during the years of observation, the occurrence of reproduction of all native amphibians has not changed.

For the diet analysis we examined the stomach contents of 21 specimens of adult green frog and 42 specimens of adult African clawed frog. We found a total of 16 Orders, three of which (Hemiptera, Hymenoptera and Diptera) are present both in green frogs and in African clawed frogs (Table 3). In the green frogs we found mostly non-aquatic prey (83.3\%) belonging to six Orders of arthropods, while in the African clawed frogs we found mostly aquatic prey (95\%) belonging to 12 orders of arthropods, and tadpoles of one amphibian species (African clawed frog). The Pianka Index showed a value of 0.01 indicating the almost total absence of overlap of trophic niches. Amongst the aquatic prey present in both amphibians (Hemiptera and Diptera), a clear difference is apparent: the prey found in the green frog stomachs belong mainly to Families of organisms living on the water surface, while prey present in the African clawed frogs stomachs belonged to Families of organisms living within the water column. Amongst the terrestrial prey, only the Order Hymenoptera occurs in both amphibians and with only one Family (Formicidae). Eggs, tadpoles and postmetamorphs of native amphibians were not present in the stomachs of the African clawed frog examined. Nevertheless, although the samplings were conducted during the reproductive period of green frog and Italian tree frog, spawning and tadpoles were not observed in the pond.

\section{Discussion}

Our results indicate different occurrence of reproduction of green frog, painted frog and Italian tree frog between ponds with and without African clawed 
Table 3 Systematic list of the percentage of prey types in stomach contents of Pelophylax synklepton esculentus and Xenopus laevis

\begin{tabular}{|c|c|c|c|c|}
\hline Order & Family & $\begin{array}{l}\text { Ecological } \\
\text { category }\end{array}$ & $\begin{array}{l}\text { Pelophylax } \\
\text { esculentus } \\
(\%) \mathrm{n}=21\end{array}$ & $\begin{array}{l}\text { Xenopus laevis } \\
\text { (\%) } \mathrm{n}=42\end{array}$ \\
\hline Acarina & & A & - & 1.2 \\
\hline Cladocera & & A & - & 6.4 \\
\hline Calanoida & & A & - & 0.1 \\
\hline Ciclopoida & & A & - & 29.6 \\
\hline Isopoda & & NA & 12.8 & - \\
\hline Collembola & & A & - & 0.3 \\
\hline Odonata & & NA & 8.5 & - \\
\hline Ephemeroptera (nymphs) & & A & - & 17.9 \\
\hline Odonata (nymphs) & & A & - & 21.4 \\
\hline \multirow[t]{8}{*}{ Hemiptera } & Naucoridae & A & 2.1 & - \\
\hline & Micronectidae & A & - & 0.3 \\
\hline & Notonectidae & A & - & 1.6 \\
\hline & Pleidae & A & - & 4.2 \\
\hline & Gerridae & A & 2.1 & 0.2 \\
\hline & Hebridae & NA & 2.1 & - \\
\hline & Mesoveliidae & NA & 14.9 & - \\
\hline & Coreidae & NA & 4.3 & \\
\hline Tricoptera (larvae) & & A & - & 0.3 \\
\hline Lepidoptera (larvae) & & A & - & 0.1 \\
\hline Coleoptera & & NA & 4.3 & - \\
\hline \multirow[t]{3}{*}{ Hymenoptera } & Formicidae & NA & 4.3 & 0.2 \\
\hline & Vespidae & NA & 25.4 & - \\
\hline & Apidae & NA & 4.3 & - \\
\hline Diptera & & NA & 8.5 & - \\
\hline Diptera (pupae) & & A & - & 1.5 \\
\hline \multirow[t]{4}{*}{ Diptera (larvae) } & Chaoboridae & A & - & 0.6 \\
\hline & Culicidae & A & 6.4 & 2.0 \\
\hline & Ceratopogonidae & A & - & 2.8 \\
\hline & Chironomidae & A & - & 8.6 \\
\hline Anura & & A & - & 0.7 \\
\hline
\end{tabular}

$A$ aquatic, $N$ non-aquatic. Rows in bold indicate prey common to both Pelophylax and Xenopus
(Cruz et al. 2006; Hartel et al. 2007; Orizaola and Braña 2006). Moreover, the reproductive activity of the common toad in the study area occurs during the coldest months (December/February), when the activity of African clawed frogs is low due to low temperatures (Casterlin and Reynolds 1980; Measey 2001). The predation on conspecific tadpoles confirms the significant cannibalistic behaviour of this species (Tinsley et al. 1996; Measey 1998; Faraone et al. 2008b).

The consequences of biological invasions are usually predicted as undesirable and detrimental. However, in many cases it is difficult to assess 
objectively the impact of an alien species. So, often the precautionary principle is the main subject of aversion against the introduction of alien species in a new area (Cooney 2004) or, at the worst, the knowledge of the effects of species with similar ecological features can suggest its undesirability. In other cases the consequences of biological invasions are concrete and well known (Holway et al. 2002; Courchamp et al. 2003).

Following Parker et al. (1999) to assess the impact of an invasive species it is not sufficient to know the effect on native species or ecosystems, but the impact must be considered as the product of three factors: the range size of the invader species, its average abundance per unit area across that range (in number of individuals, biomass, or other relevant measure) and the effect per individual or per biomass unit of the invader. So, if the three factors of the Parker equation have high values, the value of the impact is high. In this study we observed and increment of $17.6 \%$ of ponds colonized by African clawed frog in four years. Moreover, Faraone et al. (2008a) recorded the African clawed frog's Sicilian range of distribution measuring $\sim 225 \mathrm{~km}^{2}$ in 2006 , evaluated by using the Minimum Convex Polygon method. Our successive studies show an enlarging area of more of $300 \mathrm{~km}^{2}$ in 2009 and an estimation of population in a focal pond by using capture-mark-recapture method of about 2100 adult African clawed frogs in a single pond (Lillo et al. unpublished data). These data, together with the results of the present study, represent the three factors of the Parker equation with high values. So seem appropriate to asses high the impact of the African clawed frog on the Sicilian amphibians.

African clawed frog has been so far considered an undesirable species more for potential effects on native species than for the knowledge of its effective consequences on host ecosystems (Ricciardi and Cohen 2007). Indeed studies on the biology and the ecology of African clawed frogs in their invasive environments conducted in Chile, USA, France, Portugal and Wales did not clarify the effects of interactions between the alien species and the native species, and in particular the impact on native amphibians (e.g., Fouquet and Measey 2006; Lobos and Jaksic 2005; Measey and Tisley 1998). Instead, our results for the first time, show an association between the presence of African clawed frog and a concrete decline of the reproduction occurrence of three native amphibians.

The diet comparison between African clawed frog and green frog, points out the strong preference of green frogs towards terrestrial prey, as already known (Lőw and Török 1998; Sas et al. 2007), and the almost absolute preference of African clawed frogs towards aquatic prey (see Faraone et al. 2008b; Measey 1998). The observed predation on Formicidae by African clawed frog probably depends mainly on occasional ingestions of organisms accidentally fallen in the water (see Measey 1998; Tinsley et al. 1996). These data, at the same time as the almost total absence of overlap of the trophic niche indicated by Pianka Index, suggest the lack of competition for trophic resources between the two species, and probably also between the alien species and the other two semi-terrestrial native amphibians that feed overground. At the same time our data does not permit to support or to discard an impact hypothesis due to direct predation on eggs or larvae of native amphibians. It is possible that the high density of African clawed frogs and the low density of native larvae could decrease the probability to detect these in the stomach contents. On the other hand the difficulty to record the direct predation was already presumed by Measey (1998). He describes that Rana temporaria spawned in a pond colonized by African clawed frog in Wales, and that numbers of larvae were monitored. Later no tadpoles or postmetamorphic could be found, but, at the same time, no larvae were found in the stomach contents of African clawed frogs.

So currently it is not possible to point out the conclusive mechanisms of impact of African clawed frog on native amphibians, and new studies will be necessary to clarify this aspect. In particular in the future it will be useful to test if the African clawed frog direct predation can be the main process of native amphibians decline that we observed in our study. Other studies are necessary, in Sicily or in other new colonized areas, to asses the ecological fall of African clawed frog introduction of freshwater ecosystems and in particular on invertebrate community

Despite the insular isolation of Sicily which can prevent the undesirable dispersal of the alien species in other geographic areas, insular communities and 
amphibian populations are considered particularly vulnerable to biological invasions (Collins and Storfer 2003; Savage 1987). So the effects of African clawed frog invasion reported in this study is cause for high concern. Efficacy control methods should be tested to allow quick and proportionate interventions of population control to avoid the detriment to the Sicilian amphibians populations.

Acknowledgments We thank to three anonymous referees who contributed helpful comments that strengthened considerably the final version of the manuscript. Special thanks go to all the students and trainees who contributed to the field data collection. We are grateful to all farmers who permitted the scientific activity in private lands and ponds. We thank John J. Borg and Fabrizio Li Vigni for the language revision. This study was financially supported by "MIUR Ex $60 \%$ 2007". The legal permission for this study were allowed by the "Ministero dell'Ambiente e della Tutela del Territorio e del Mare-Direzione Protezione Natura (Prot. DPN-20070014605 of 25 May 2007)".

\section{References}

Beebee TCJ, Griffiths RA (2005) The amphibian decline crisis: a watershed for conservation biology? Biol Conserv 125:275-281

Casterlin ME, Reynolds WW (1980) Diel activity and thermoregulatory behaviour of a fully aquatic frog: Xenopus laevis. Hydrobiologia 75:189-191

Collins JP, Storfer A (2003) Global amphibian declines: sorting the hypotheses. Divers Distrib 9:89-98

Cooney R (2004) The precautionary principle in biodiversity. Conservation and natural resource management: an issues paper for policy-makers, researchers and practitioners. IUCN, Gland Cambridge

Courchamp F, Chapuis J, Pascal M (2003) Mammal invaders on island: impact, control and control impact. Biol Rev 78:347-383

Crayon JJ (2005) Species account: Xenopus laevis. In: Lannoo MJ (ed) Amphibian declines: the conservation status of United States species, vol 2. University of California Press, Berkeley, pp 522-525

Cruz MJ, Rebelo R, Crespo G (2006) Effects of an introduced crayfish, Procambarus clarkii, on the distribution of south-western Iberian amphibians in their breeding habitats. Ecography 29:329-338

Eggert C, Foquet A (2006) A preliminary biotelemetric study of a feral invasive Xenopus laevis population in France. Alytes 23:144-149

Elepfandt A (1996a) Sensory perception and the lateral line system in the clawed frog, Xenopus. In: Tinsley RC, Kobel HR (eds) The Biology of Xenopus. Oxford University Press, Oxford, pp 97-116

Elepfandt A (1996b) Underwater acoustics and hearing in the clawed frog, Xenopus. In: Tinsley RC, Kobel HR (eds)
The Biology of Xenopus. Oxford University Press, Oxford, pp 177-191

Elepfandt A, Eistetter I, Fleig A, Gunther E, Hainch M, Hepperle S, Traub B (2000) Hearing threshold and frequency discrimination in the purely aquatic frog Xenopus laevis (Pipidae): measurement by means of conditioning. J Exp Biol 203:3621-3629

Faraone FP, Lillo F, Giacalone G, Lo Valvo M (2008a) The large invasive population of Xenopus laevis in Sicily (Italy). Amphibi-Reptil 29:405-412

Faraone FP, Lillo F, Giacalone G, Lo Valvo M (2008b) Dieta di una popolazione di Xenopo liscio introdotta in Sicilia. In: Corti C. (Ed.), Herpetologia Sardiniae. Societas Herpetologica Italica-Edizioni Belvedere, "le scienze", Latina, pp 241-246

Fouquet A (2001) Des clandestins aquatiques. Zamenis 6:10-11

Fouquet A, Measey JG (2006) Plotting the course of an African clawed frog invasion in Western France. Anim Biol 56:95-102

Garner TWJ, Perkins MW, Govindarajulu P, Seglie D, Walker S, Cunningham AA, Fisher MC (2006) The emerging amphibian pathogen Batrachochytrium dendrobatidis globally infects introduced populations of the North American bullfrog, Rana catesbeiana. Biol Lett 2:455-459

Gherardi F, Bertolino S, Bodon M, Cesellato S, Cianfanelli S, Ferraguti M, Lori E, Mura G, Nocita A, Riccardi N, Rossetti G, Rota E, Scalera R, Zerunian S, Tricarico E (2008) Animal xenodiversity in Italian inland waters: distribution, modes of arrival, and pathways. Biol Invasions 10:435-454

Gurdon J (1996) Introductory comments: Xenopus as a laboratory animal. In: Tinsley RC, Kobel HR (eds) The Biology of Xenopus. Oxford University Press, Oxford, pp 3-6

Hartel T, Szilárd N, Cogalniceanu D, Öllerer K, Moga CI, Demeter L (2007) The effect of fish and aquatic habitat complexity on amphibians. Hydrobiologia 583:173-182

Hecnar SJ, M'Closkey RT (1997) The effects of predatory fish on amphibian species richness and distribution. Biol Conserv 79:123-131

Holway DA, Lach L, Suarez AV, Tsutsui ND, Case TJ (2002) The causes and the consequences of ant invasions. Annu Rev Eco Syst 33:181-233

Ihmied YM, Taylor EW (1995) Effect of temperature on surfacing behaviour in Xenopus laevis. J Therm Biol 20:49-53

Kats LB, Ferrer RP (2003) Alien predators and amphibians decline: review of two decades of science and the transition to conservation. Divers Distrib 9:99-110

Keller RP, Lodge DM (2007) Species invasions from commerce in live aquatic organisms: problems and possible solutions. Bioscience 57:428-436

Kolar CS, Lodge DM (2001) Progress in invasion biology: predicting invaders. Trends Ecol Evol 16:199-204

Lafferty KD, Page CJ (1997) Predation on the endangered tidewater goby, Eucyclogobius newberry, by the introduced African clawed frog, Xenopus laevis, with notes on the frog's parasites. Copeia 3:589-592 
Lanza B, Andreone F, Bologna M, Corti C, Razzetti E (2007) Fauna d'Italia Vol XLII, Amphibia. Calderini, Bologna

Lillo F, Marrone F, Sicilia A, Castelli G, Zava B (2005) An invasive population of Xenopus laevis (Daudin, 1802) in Italy. Herpetozooa 18:63-64

Lobos G, Jaksic FM (2005) The ongoing invasion of the African clawed frog (Xenopus laevis) in Chile, causes of concern. Biodivers Conserv 14:429-439

Lobos G, Measey GJ (2002) Invasive population of Xenopus laevis (Daudin) in Chile. Herpetol J 12:163-168

Lőw P, Török J (1998) Prey size selection and food habits of water frogs and moor frogs from Kis-Balaton, Hungary (Anura: Ranidae). Herpetozoa 11:71-78

Measey GJ (1998) Diet of feral Xenopus laevis (Daudin) in South Wales. U.K. J Zool 246:287-298

Measey GJ (2001) Growth and ageing of feral Xenopus laevis (Daudin) in South Wales, UK. J Zool 254:547-555

Measey GJ, Tisley RC (1998) Feral Xenopus laevis in South Wales. Herpetol J 8:23-27

Orizaola G, Braña F (2006) Effect of salmonid introduction and other environmental characteristics on amphibian distribution and abundance in mountain lakes of northern Spain. Anim Conserv 9:171-178

Parker IM, Simberloff D, Lonsdale WM, Goodell K, Wonham M, Kareiva PM, Williamson MH, Von Holle B, Moyle PB, Byers JE, Goldwasser L (1999) Impact: toward a framework for understanding the ecological effects of invaders. Biol invasion 1:3-19

Pianka ER (1973) The structure of lizard communities. Annu Rev Ecol Syst 4:53-74

Rebelo R, Amaral P, Bernardes M, Oliveira J, Pinheiro P, Leitao D (2010) Xenopus laevis (Daudin 1802), a new exotic amphibian in Portugal. Biol invasions DOI 10.1007/s10530-010-9757-0

Ricciardi A (2007) Are modern biological invasions an unprecedented form of global change? Biol Conserv 21:329-336

Ricciardi A, Cohen J (2007) The invasiveness of an introduced species does not predict its impact. Biol Invasions 9:309-315

Sala OE, Chapin FS, Armesto JJ, Berlow E, Bloomfield J, Dirzo R, Huber-Sanwald E, Huenneke LF, Jackson RB,
Kinzig A, Leemans R, Lodge DM, Mooney HA, Oesterheld M, Poff NL, Sykes MT, Walker BH, Walker M, Wall DH (2000) Biodiversity: global biodiversity scenarios for the year 2100. Science 287:1770-1774

Sas I, Kovács ÉH, Covaciu-Marcov SD, Strugariu A, Covaci R, Ferenţi S (2007) Food habits of a Pool frog Pelophylax lessonae-Edible frog Pelophylax kl. esculentus population from North-Western Romania. Biota 8:71-78

Savage JA (1987) Extinction of an island forest avifauna by an introduced snake. Ecology 68:660-668

Scott NJ, Woodward BD (1994) Surveys at breeding sites. In: Heyer WR, Donnelly MA, McDiarmid RW, Hayek LA, Foster MS (eds) Measuring and monitoring biological diversity, standard methods for amphibians. Smithsonian Institution Press, Washington, pp 183-205

Sicilia A, Lillo F, Zava B, Bernini F (2006) Breeding phenology of Bufo viridis Laurenti, 1768 in Sicily. Acta Herpetol 1:107-117

Solé M, Beckmann O, Pelz B, Kwet A, Engels W (2005) Stomach-flushing for diet analysis in anurans: an improved protocol evaluated in a case study in Araucaria forests, southern Brazil. Stud Neotrop Fauna Environ 40:23-28

Tinsley RC, McCoid MJ (1996) Feral Population of Xenopus outside Africa. In: Tinsley RC, Kobel HR (eds) The Biology of Xenopus. Oxford University Press, Oxford, pp 81-94

Tinsley RC, Loumont C, Kobel HR (1996) Geographical distribution and ecology. In: Tinsley RC, Kobel HR (eds) The Biology of Xenopus. Oxford University Press, Oxford, pp 35-59

Videler JJ, Jorna JT (1985) Functions of the sliding pelvis in Xenopus laevis. Copeia 1:254-257

Weldon C, Du Preez LH, Hyatt AD, Muller R, Speare R (2004) Origin of the amphibian Chytrid Fungus. Emerg Infect Dis 12:2100-2105

Weldon C, De Villiers AL, Du Preez LH (2007) Quantification of the trade in Xenopus laevis from South Africa, with implications for biodiversity conservation. Afr J Herpetol $56: 77-83$ 